\title{
VOZ EM ESTADO DE MOVÊNCIA: o saber corpóreo e político das vocalidades da cena em Água, Flores e Anjinhos e baldio
}

VOICE IN STATE OF MOUVANCE: the corporeal and political knowledge of the vocalities in scene in Water, Flowers and Little Angels and wasteland

Héctor Briones ${ }^{1}$

Juliana Rangel Pereira ${ }^{2}$ 


\section{Resumo}

O presente artigo aborda as vocalidades em suas movências na cena teatral a partir de duas montagens realizadas na cidade de Fortaleza (CE), Nordeste brasileiro: Água, Flores e Anjinhos e baldio. Com estas montagens se indaga sobre uma dimensão sensória da voz, dando a perceber os seus alcances poéticos, como uma força performativa que conecta corpo, memória e cena, na qual se evidenciam intensivas marcas políticas, como ecos de um outro tempo no tempo presente desse Nordeste.

Palavras-chave: Voz; corpo; movência; política; cena contemporânea

\section{Abstract}

The present article approaches the vocalities in their motions in the theatrical scene from two mounts performed in Fortaleza (CE) city, Brazil Northeast: Water, Flowers and Little Angels and wasteland. With these mounts ask yourself into a sensory dimension of the voice, giving notice to their poetic reaches, as a performative force that connects body, memory and scene, in which intense political marks are evidenced, as another time echoes in the present time of this Northeast.

Keywords: Voice; body; mouvance; politics; contemporary scene

ISSN: 1414.5731

E-ISSN: 2358.6958

Professor doutor adjunto, Instituto de Cultura e Arte - Universidade Federal do Ceará atuando no Curso de Teatro-Licenciatura; no Mestrado em Artes; e no ProfArtes. hecandres@yahoo.com

2 Professora doutora adjunta, Instituto de Cultura e Arte (ICA) - Universidade Federal do Ceará. julianarangelfp@yahoo.com.br 
Observem as palavras que acabo de utilizar: energia, força, trabalho, mudança e mobilização. [...]. Se a performance é o aspecto teatral do corpo em movimento, clarifiquemos em seguida que esse corpo da performance não é o corpo só individual e biológico senão corpo social.

Magaly Muguercia (2009)

Pensar o teatro a partir da voz, da vocalidade poética, nos abre uma dimensão corpórea da cena, capaz de produzir um tumulto em nossos acostumados hábitos e representações, evidenciando uma diferença constitutiva do presente - este tempo nosso - e que o presente da cena fende e abre. Essa dimensão corpórea é também social, "corpo-social" - mas de que modo? Como este presente social pode ser pensado, em suas diferenças, a partir das vocalidades poéticas da cena? Esta questão permitirá indagar, neste artigo, a interface voz-memória-política na cena teatral. Para pensar esta tríade será valioso abordar o conceito de movência, proposto por Paul Zumthor (2001), termo-chave neste artigo.

Para pensar esta problemática poética abordaremos duas montagens teatrais dirigidas pelos autores deste artigo e que integram o Laboratório de Poéticas Cênicas e Audiovisuais (LPCA) ${ }^{4}$, a saber: Água, Flores e Anjinhos 5 , inspirado no texto Flores D'América do autor potiguar João Denys, e baldio ${ }^{6}$, realizado com o grupo de teatro cearense Pavilhão da Magnólia. As duas montagens operam o trabalho vocal em um plano expandido do texto, abrindo, dilatando as palavras em ressonâncias experimentadas no corpo-vocal. De modo semelhante as mesmas são atravessadas por diferentes realidades socioculturais do Nordeste brasileiro, as quais influenciaram os respectivos processos de criação destas montagens. Isto permitirá pensar a íntima relação do trabalho vocal da cena com esse corpo-social, posto acima com Muguercia, além de evidenciar como os artistas cearenses, nordestinos, vêm desdobrando suas poéticas na contemporaneidade, na tentativa de abrir outras leituras, outras representações, que venham a destravar e ampliar os seus imaginários.

Neste âmbito, pensar a voz no teatro é também pensar no teor sensório das palavras - é o que se quis experimentar nas duas montagens, marca performativa que constitui as suas dramaturgias.

\section{Das texturas dramatúrgicas}

Água, Flores e Anjinhos indaga, no texto de João Denys, sobre a dimensão popular de coros, de rezas, cantos de cegas sanfoneiras, de mulheres do cangaço $\ \mathrm{e}$ a faz instigada pela textura da dramaturgia deste autor. Para o grupo há uma força

\footnotetext{
3 "Observen las palabras que acabo de utilizar: energía, fuerza, trabajo, cambio y movilización. [...] Si la performance es el aspecto teatral del cuerpo en movimiento, aclaremos enseguida que ese cuerpo de la performance no es solo individual y biológico sino cuerpo social." (Muguercia, 2009, p. 136 -137) - (Tradução nossa).

${ }^{4}$ Grupo de pesquisa cênica do Instituto de Cultura e Arte da Universidade Federal do Ceará (ICA-UFC). Este grupo se dedica a pesquisar as interfaces dos elementos da cena em uma dinâmica processual, interessando-se pelas diversas fricções entre os seus múltiplos teores sensórios: corpo, voz, imagem, som, espaço, palavra, entre outros. Podem-se acessar imagens e vídeos das duas montagens aqui citadas no portfólio virtual deste grupo de pesquisa, indicado nas referências. ${ }^{5}$ Montagem resultado do laboratório de pesquisa de doutorado, dirigido pela coautora deste artigo. Este laboratório contou com a participação de atrizes do Curso de Teatro-Licenciatura do ICA-UFC e estudantes do curso de Cinema e Audiovisual ICA-UFC. Teve sua estreia em setembro de 2013, com temporada nesse mesmo ano e também em 2014. Todo o processo de criação desta montagem integra a tese de doutorado da coautora deste artigo.

${ }^{6}$ Montagem dirigida pelo coautor deste artigo, que teve sua estreia em março de 2015, com temporadas em 2016 e 2017 . A mesma tem participado em alguns festivais como o de Guaramiranga (CE), o de Campina Grande (PB), o de Campinas (SP), entre outros, sendo parte do repertório do grupo teatral cearense Pavilhão da Magnólia.
} 
corpórea e sinestésica da palavra no texto Flores D'América - e seu interesse pelas partes de coro presentes no texto advém do fato de perceber nele há um rico material de trabalho para explorar uma vocalidade poética, como um encontro de vozes. Deste modo, o grupo se apropriou das palavras do texto como uma materialidade fonética, por meio de efeitos assumidamente sonoros, fonéticos, musicais, sensoriais, que terminaram por configurar a sua poética cênica. Debruçou-se, então, na pesquisa sonora de trechos como o que segue abaixo, o qual foi dito em cena a várias vozes, em um ritmo sincopado e ágil, sendo algumas de suas palavras lançadas livremente por algumas das atrizes, às vezes estridentemente no espaço da cena, rasgando o denso murmúrio gerado pelas outras vozes. Este coro dialogava com a imagem de uma grande boca projetada em uma das telas do cenário. $O$ trecho foi o seguinte:

\section{Líder do Coro:}

Foge, foge, passa, passa, esconde esconde uruçu, mandaçaia, tubiba, mosquito, papa-terra voa. Voa, voa, voa exu, miduri, capuxu doce. Doce, foge, voa, passa, esconde, voa. [...] Foge dada, foge cila, foge moça. Olha a faca, Rosinha, olha a sede, Lili, olha a bala Veroniquinha. Puxe linha, dona Otília, geme geme, Inacinha.

\section{Coro:}

Passa xexéu, passa baraúna, passa socó, passa nabu, passa passa gavião, passa umbu, passa tatu, passa boi, passa boiada, passa Bandeira, passa umburana, passa sol, passa angico, passa e fica, passa passa, passa pó, passa poeira, passa pau, nuvem passa, passa vento, passa passa, corre corre, fogo fogo, corta corta, puxa, puxa, esconde a linha, sai da linha, vá pra linha, arroucha afrouxa. São pontos, são galhos, são linhas, são flores, são traços, são folhas, corta estica. É rosa, é vinho, é azul real, é verde, é amarelo ouro. Será sangue sangue, corre corre será. (Denys, 2005, p. 74)

Outro aspecto que serviu de mote para a pesquisa da vocalidade nesta montagem foi a investigação da visceralidade da palavra, encontrando ressonância para tal na figura da vaca, do urro da vaca - elemento que o grupo quis investigar também na dramaturgia de Denys:

\footnotetext{
Soledade: (perversa, entre dentes) Maledita! Sangue, sangue, cascavel, porca, porcalha, (urra) coisa suja, porcaria, veia, veia, cangote, estouro, (relincha) cruz credo, fogo do inferno, arde, arde, arde, lama de sangue, (relincha) arranca, arranca, esfola, tripa, cangote, arranca. Arre! Arranca olho, corta orelha, arranca língua, tira o couro, quebra venta! Podre, temba, careca, azougada! (tira as mãos da cabeça e manipula as chaves grandes e velhas) Errante, errante, setenta vezes sete, Irad, sete, sete, sete. Sela, sela, Ada, Ada, ferida, pereba, ira, nó, tirana, nó, vagabunda, pedra fugitiva, horas abertas, terra perdida, palmatória, marreca, cara macambira, carão, urtiga, cunanam, caçote, capuxu, socó, toitiço, quixaba, cachaço. (numa longa dor) Maledita! (Denys, 2005, p. 75)
}

Assim sendo, esta montagem, trabalhando somente com atrizes, pesquisou tanto a força da voz nos coros de mulheres como um vigor selvagem que se dá no encontro da voz com a palavra, de maneira encarnada, corpórea, visceral, principal aspecto poético no processo de criação desta montagem.

No caso de baldio, montagem que se deu em um processo colaborativo, a partir de histórias reais contadas pelos próprios atuantes, sendo acompanhado por um dramaturgista, o escritor paraibano Astier Basílio. Com o mote disparador de 
contar vivências que tivessem deixados nos integrantes do grupo marcas sensíveis, entre a violência e a delicadeza foram surgindo histórias com evidentes situações de abandono, de amores e sonhos perdidos, de dores e pequenas alegrias, que foram nos mostrando uma percepção outra da cidade, um lugar marginal da mesma. Não obstante a centralidade pessoal destas vivências, foi justamente o seu vínculo com a cidade (de Fortaleza e de outras cidades do interior do Ceará) e com o social o que mais instigou o processo. Processo esse inspirado também no conto Velório do australiano Shaun Tan (2009), que disparou a relação entre violência e delicadeza, onde a figura do cão, mais precisamente do vira-lata em seu desamparo, foi ganhando força poética para o processo de criação cênica. Estas histórias foram o material de trabalho para a dramaturgia textual desta montagem, sendo construída em paralelo à dramaturgia da cena.

A linguagem coloquial inicial com que estas histórias foram contadas foi ganhando outras intensidades sonoras durante a construção das cenas, sobretudo a partir da força do uivo, plasmada na figura do cão. O grupo começa a pesquisar a potência rítmica e sonora das palavras, quando, por exemplo, trabalha com frases curtas, onde duas atrizes contam uma das histórias, por meio de repetições e frases inacabadas em um tom seco e ágil:

DENISE: Cuidado!

SILVIANNE: Cuidado?

DENISE: É que por causa desse convênio, a instituição que eu trabalhava recebia...

SILVIANNE: Cuidado onde você está pisando!

DENISE: "Você não sabia?", insistiu ela, me perguntando.

SILVIANNE: Eu sempre imaginei que quando chegasse o século vinte e um...

DENISE: Que lugar é esse?

SILVIANNE: Eu sempre imaginei que quando chegasse o século vinte e um...

DENISE: Esse lugar pra onde você está indo?...

SILVIANNE: Mas aí quando você pensa que não, quando você imagina que não, vem essa merda toda e... (Basílio, Pavilhão da Magnólia, 2015) ${ }^{7}$

Outro exemplo pode ser percebido no trecho abaixo, praticamente sem pontuação, em um fluxo de palavras, que é também um fluxo de imagens. Aqui o ator iniciava lentamente a fala e a cada frase ia intensificando a velocidade e agressividade da mesma, inspirado na figura do cão, do uivo:

ELIEL - (uivo longo e suave) - Eu vi um filme nele um bicho latia não sei se era cachorro porque era vermelho, ele latia muito do lado tinha um homem mas o que eu queria dizer era que o bicho que era vermelho latia latia muito alto latia muito forte era vermelho e eu não sabia para onde olhar [...] o filme estava numa cena onde o homem jogava suas roupas. Ele chorava, e chorava, ele chorava, não quis mais ver o filme porque não sabia como olhar para a cena. E chovia, chovia, chovia, chovia.... (silêncio ... uivo longo e suave) (Basílio, Pavilhão da Magnólia, 2015).

${ }^{7}$ Respeitamos aqui a versão final do texto, que derivou desta montagem, onde as falas são nomeadas com os nomes dos próprios integrantes do grupo. 
Poderíamos dizer que se a força poética sonora da montagem de baldio está no uivo, em Água, Flores e Anjinhos é no urro que ela se encontra. Ambos os processos partem de figuras animais para suas composições, forças que dão a perceber, sobretudo, o jogo sensório-vocal da cena. Aqui a voz se torna ação e exige dos atores um trabalho eminentemente corpóreo para além do sentido semântico das palavras. Uma das atrizes de baldio chega a comentar, sobre seu trabalho em cena:

A questão da respiração nas palavras é base, aqui o diafragma é a base da construção da cena inteira, porque é a partir dele que eu consigo criar. (Depoimento da atriz Silviane Lima, 2017) ${ }^{8}$

Na prática, este comentário explicita que a voz não está dada até o momento em que soa e não perdura para além da respiração com a qual abandona o corpo, tendo que ser gerada cada vez novamente no corpo (Fischer-Lichte, 2011). Neste tipo de trabalho, a ação vocal preenche o ambiente de criação, torna-se um encontro, um envolvimento sonoro. Nesta perspectiva, a vocalidade poética transpõe os limites tradicionais da cena, relacionando intensamente palco e plateia, expandindo a fala articulada ao se esparramar no inarticulado, nos gemidos, sussurros, respirações, compondo assim uma textura dramatúrgica geradora de sentidos sensíveis.

\section{Das sonoridades sensíveis}

Foi justamente o teor sensível da voz que impulsionou os processos de criação vocal das montagens aqui referidas. No caso de Água, Flores e Anjinhos, houve uma imersão na força sonora das festividades religiosas tradicionais do Nordeste brasileiro. De que modo mobilizar esta potência sonora nas atrizes e na cena teatral? Como as referências populares podem ser transfiguradas no corpo-vocal? Perguntas como estas foram de suma importância para o processo de criação, ao permitir transitar no campo da voz enquanto performance (no teatro, na música, na dança), entendendo a voz como criação de linguagem, inundada por reminiscências de vocalidades poéticas das tradições populares. Os cantos, seus sons, possibilitavam esgarçar as palavras do texto, alcançar intensidades sonoro-vocais inusitadas nas atrizes, explorando outros registros fora das convenções tradicionais do canto religioso, expandido poeticamente suas sonoridades. Foram significativos, durante o processo de criação desta montagem, os cantos religiosos trazidos pelas próprias atrizes como parte de suas memórias, nos quais as melodias eram experimentadas nas palavras do texto, com variações sonoras, alongando, encurtando, mudando tons, encontrando outras texturas vocais - cantos religiosos esses que entraram na cena como ecos desses cantos vibrando nas vozes das próprias atrizes.

Desta maneira, não se tratou de indagar a vocalidade poética em um sentido imitativo, com respeito à tradição como em um folclorismo tradicional fixo. O respeito se deu aqui no sentido de aprender com a força dessas vozes rasgadas, entoadas em uma desgastada e intensa vibração e de um ressoar infinito que faz cantar todo

${ }^{8}$ Todos os depoimentos dos atores e atrizes de baldio são parte de uma entrevista realizada com os mesmos em setembro de 2017, sobre o processo de criação e apresentações desta montagem. 
o corpo. Os cantos religiosos pedem pelos seus e pelos outros, numa polifonia de encontros de vozes, em sua maioria vozes femininas, que cantam há muitos anos, memórias vivas de um passado longínquo que se reatualizam nas manifestações populares hoje.

Nesse contexto, as noções de tradição e memória, implicadas na noção de movência, do medievalista e estudioso da voz Paul Zumthor, se tornam importantes para este artigo. Segundo Zumthor, a tradição não é fixa, senão móvel, em fluxo, permeando de forma abrangente o atual, o nosso presente.

No caso de baldio, o tom coloquial dos relatos das vivências das atrizes e atores, entre a violência e a delicadeza, forneceu um teor vocal inicial praticamente de testemunho, uma espécie de teatro-documentário. Relatos em baixo volume, enunciados de maneira aparentemente neutra e em ritmo lento, deu passagem, a partir da figura do cão, a uma sonoridade gutural que foi sendo explorada aos poucos no processo de criação. Como acima referido, nestes relatos nos foi evidenciada uma cidade outra, marginal, desconjuntada, permitindo que os mesmos fossem adquirindo uma dimensão praticamente onírica - o que deu passagem para operar nas palavras aliterações, com frases entrecortadas, e as diversas memórias que se cruzavam na mesma narração de um só ator. Assim, foram criados textos que desafiaram os atores e as atrizes a indagar vocalmente possibilidades radicalmente distintas do tom documental, o qual também fez parte da montagem.

Nesta montagem operamos com microfones, elemento que permitiu uma outra textura, de ampliação do volume das falas que eram ditas em um tom intimista, assim como a reverberação em todo o espaço da cena de outros jogos vocais obrigando, inclusive, a desenhar uma espacialização específica das caixas de som, de maneira diagonal. O tom intimista, a modo de exemplo, ganhou simultaneamente um aspecto suave e desconcertante, pelos fatos narrados serem de violência urbana e discriminação sexual. Como comenta um dos atores desta cena:

[...] aquela cena é difícil não só pela questão do texto, mas é o tom do texto, o som da voz, o peso que a voz tem que ter, que por estar com microfone se torna uma paisagem na cena. (Depoimento do ator Jota Júnior, 2017)

Dessa maneira, a narração é estendida em todo espaço da cena, como se estivesse sendo dita nos ouvidos dos espectadores, pelo efeito tecnológico dos microfones, expondo o teor sensório e afetivo da cena.

O que se abre aqui é uma operação cênica da vocalidade que expõe, nas duas montagens, a 'presença' da singularidade vocal de cada atriz e cada ator. Um pensar/ agir da voz como corpo, com toda a sua materialidade que é física, corpórea, tátil, capaz de mexer com o espaço, provocando vibrações físicas da voz na cena. O que está em jogo, porém, nestas vibrações, nesta 'presença'? Considere-se que estes trabalhos partem de referentes poéticos evidentemente distintos: o primeiro indagando sobre um Nordeste a partir de suas tradições populares, sem cair em uma fixação turístico-folclórica; o segundo, indagando sobre um Nordeste urbano, ou mais pre-

${ }^{9}$ Técnica de claro-escuros criado por Leonardo Da Vinci, no Renascentismo. A técnica evidencia os índices de luminosidade, o que reforça a sugestão de volume dos corpos.

${ }^{10} \mathrm{O}$ termo "verbos de ação" utilizado aqui, tem relação com cada elemento e os aspectos qualitativos que o movimento deles me estimula no ato criador. 
cisamente, suburbano e globalizado. Contudo, não obstante as diferenças, podemos dizer que ambos se unem ao indagar sobre uma marginalidade, social e histórica, que impacta seus processos criativos, provocando outros modos no tratamento da voz em cena. Trata-se de uma sensibilidade vocal convulsionada por outros Nordestes, diversos, abrindo imaginários que ecoam na cena, na força das vozes.

Por outro ângulo, tampouco se quer aqui substancializar o trabalho vocal como um centro poético da cena. Quando se diz que a sonoridade vai para além do sentido semântico das palavras, se quer dizer que as expande e não necessariamente que as oblitera. Há uma tensão crítica entre estes dois elementos, voz e palavra, advinda de uma tradição logocêntrica que tem sistematicamente negado o primado da voz, considerando-a como resto insignificante da palavra (Cavarero, 2011). Assim sendo, é precisamente o jogo combinatório - de relação, de movimento - que pode se dar entre essas duas unicidades (Cavarero, 2011, p. 31), voz e palavra, que vai aqui importar. E dar atenção à potência sonora da voz não significa exaltar uma fisicalidade originária, um reino extraverbal (Cavarero, 2011, p. 28). A fisicalidade da voz - pulmão, garganta, respiração, enfim, corpo - aponta para uma unicidade, uma singularidade da voz, que diz sobretudo do seu teor relacional, implicando outras pessoas, outros corpos.

\section{Da movência}

É neste contexto que podemos destacar o termo movência, que Paul Zumthor (2001) desdobra do filólogo espanhol Ramón Menéndez-Pidal, e que permitirá, neste artigo, indagar a vocalidade poética enquanto corpo, ou seja, corpo-social (Muguercia, 2009, p. 138). O termo movência indica um traço performativo crucial que a vocalidade poética da cena realiza, pois abre uma dupla perspectiva da voz, de profecia e memória, que Zumthor relaciona com a instância do social. E se este autor o faz pensando na tradição oral medieval, o que importa é como esta marca oral perpassa a contemporaneidade, muitas vezes de maneira crítica com esta.

No termo movência, esse autor percebe efetivamente o aspecto nômade da voz, que percorre espaços sensoriais. No deslocamento da voz, o corpo encontra imagens, gestos, cores, sensações, uma sinestesia também encontrada na fricção da voz nas palavras, bem como em toda a sensorialidade que acontece no ato de um encontro. É precisamente na sua espessura concreta, na tactilidade do sopro, na urgência do respiro que a voz se torna gestual. Para Zumthor (2014, p. 83), "dizendo qualquer coisa, a voz se diz", é ação, acontecimento, performance. Deveras, para ele (2014, p. 68), "na situação performancial, a presença corporal do ouvinte e do intérprete é presença plena, carregada de poderes sensoriais, simultaneamente, em vigília". A vigília, neste contexto, é, para com a coesão do grupo social, onde a voz poética expõe sua íntima relação com a memória, pois se

As vozes cotidianas dispersam as palavras no leito do tempo, ali esmigalham o real; a voz poética os reúne num instante único — o da performance - tão cedo desvanecido que se cala; ao menos produz-se essa maravilha de uma presença fugidia, mas total. [...] A voz poética é ao mesmo tempo profecia e memória [aqui reside a sua duplicidade]. (Zumthor, 2001, p. 139) 
A movência opera no exato momento desse "instante único", ou seja, da performance. Mas como? Põe-se em xeque, aqui, um sentido comum do que se entende por tradição, por memória - ampliando-a para além de uma insossa coleção de lembranças folclóricas, quando não de uma imposição valorativa da memória enquanto poder, de uma história oficial. Quando Zumthor (2001, p. 153) comenta que- e ele dá este exemplo entre diversos outros - o repertório dos poetas populares do Nordeste brasileiro daria, de alguma maneira, prova da continuidade oral da epopeia carolíngia europeia, não o faz de uma maneira linear e subjugada a uma origem. Em efeito, a mesma epopeia carolíngia, ao seguir a lógica de Zumthor, também pode ser entendida como uma enigmática continuidade de outras tradições nômades, vagabundas do tempo. Ou seja, tradições sem origem.

Há um intervalo complexo e múltiplo que este autor confere à relação da voz e da memória em performance - e para isso retoma a noção de "tradicionalismo" de Menéndez-Pidal, para quem a "assimilação do mesmo", procede da "ação contínua e ininterrupta das variantes" (apud Zumthor, 2001, p. 145). É justamente esta ação variante na tradição que Zumthor chama de movência e que diz da relação, no universo teórico-linguístico de Menéndez-Pidal, com uma percepção do mundo e do tempo multiforme e inabordável em sua completude. $O$ "tradicionalismo", então, na visão do autor espanhol, supera a tendência positivista de estabelecer uma lógica objetiva e totalizante da história, possibilitada por uma pretensa coerência interpretativa dos documentos. Para este pensador, que já no final do século XIX impacta o meio filológico e literário espanhol com seus estudos,

Os textos conservados passam a ser restos sobreviventes de um conjunto textual ainda não encontrado, portanto cada texto está inscrito em uma continuidade textual assumida como existente, ainda que somente possamos conhecê-la parcialmente. (Grau, 2005, p. 59)

Isto define a posição de Zumthor acerca da tradição oral:

A tradição, quando a voz é seu instrumento, é também, por natureza, o domínio da variante; daquilo que, em muitas obras, denominei movência dos textos. Menciono-a aqui mais uma vez, "ouvindo-a" como uma rede vocal imensamente extensa e coesa; como, à distância, literalmente o murmúrio desses séculos - quando não, por vezes, isoladamente, como a própria voz de um intérprete. (Zumthor, 2001, p. 144)

E se a ação da memória constitui a tradição, diz Zumthor (2001, p. 143), nela "nenhuma frase é a primeira. Toda frase, talvez toda palavra, é aí virtualmente, e muitas vezes efetivamente, citação". Assim, este autor dá a perceber na tradição o efeito disrruptivo da movência, que abate a autoridade paternalista da origem e que expõe o fato de que as vozes poéticas são sempre citações, insubmissas, ou seja, reinvenções. O próprio Menéndez-Pidal (apud Grau, 2005, p. 60) escreve: "o romance, ainda que fixado pelo verso, vive variantes, porque cada um que o canta o considera como casa própria, coisa de todos não é de ninguém". ${ }^{10}$ Referindo-se à vocalidade poética,

\footnotetext{
9 "Los textos conservados pasan a ser restos supervivientes de un conjunto textual no encontrado aún, y por tanto, cada texto está inscrito en una continuidad textual, asumida como existente, aunque sólo se la conozca parcialmente". (Grau, 2010, p. 59) - (Tradução nossa).

10 "el romance, aunque fijado por el verso, vive variantes, porque cada uno que lo canta lo considera como casa propia, cosa de todos pues no es de nadie" (Menendez-Pidal apud Grau, 2010, p. 60).
} 
Zumthor (2001, p. 147) comenta de uma corrente intervocal na qual em "todo texto repercute (literal e sensorialmente) o eco de vários outros textos do mesmo gênero [...] quando não, por figura contrastiva ou paródica (e, às vezes, sem objetivo determinável), o eco de todos os textos possíveis".

O que está em jogo aqui é nada mais nada menos que o que hoje se concebe como intertextualidade, multirreferencialidade, eliminando qualquer ideia de pura autenticidade, no que tange à arte contemporânea. Zumthor (2001, p. 142), com efeito, explana que a tradição oral dos poetas, trovadores, "descansa sobre uma espécie de 'memória popular' que não se refere a uma coleção de lembranças folclóricas, mas que, sem cessar, ajusta, transforma e recria". Isto posto, se a voz é para Zumthor "o domínio da variante", é ela que vai permitir também, nas palavras do texto, a movência.

Deste modo, as palavras possuem aberturas a partir das quais se dá a intertextualidade, como também acontece com a oralidade, que vai possibilitar a intervocalidade. Ambas podem ser concebidas como lugares de transformação. Ainda que algumas tradições (sejam textuais ou orais) possam ser regradas de uma maneira mais ou menos formalizada, serão sempre, de um ou outro modo, como diz Zumthor, incompletas e entreabertas ao imprevisível, ao inusitado.

E no acessar a voz movente, corpo, memória, vozes outras foram inundando os processos de criação das duas montagens já citadas, gerando texturas cênicas, vocalidades em diálogo com as imagens, afetando o corpo-voz das atrizes e dos atores.

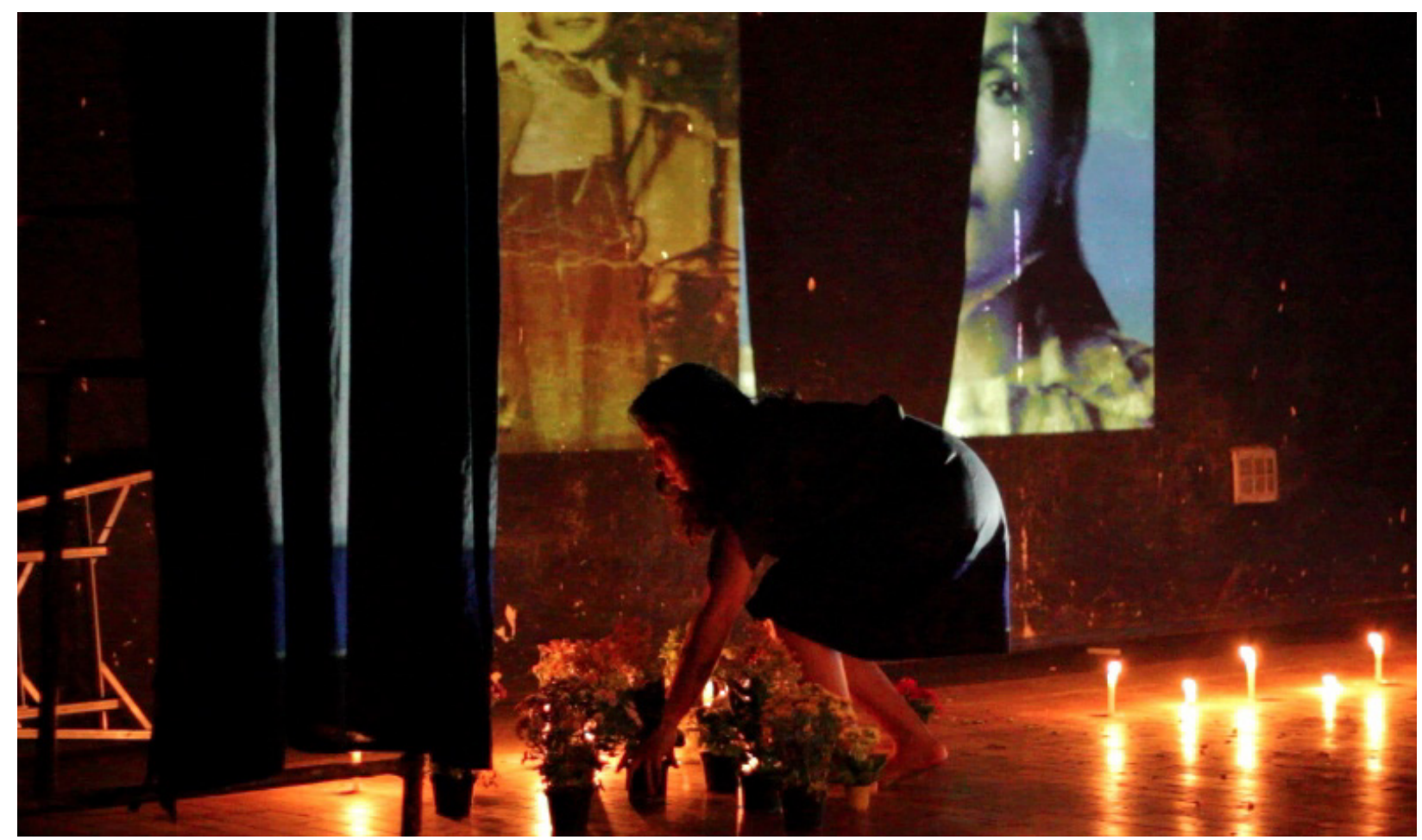

Cenário-Instalação de Água, Flores e Aninhos. Atriz: Hylnara Anny. Foto: Fábio José

Sempre que acho que vou para outro som, outro movimento, outra lembrança, outra morte me invade. Não tem fim. (Manuscrito da Atriz Roberta Bernardo - Água, Flores e Anjinhos, 2013). ${ }^{11}$

\footnotetext{
${ }^{11}$ Todos os manuscritos que constam neste artigo foram feitos pelas próprias atrizes durante o processo de criação desta montagem, durante 0 ano de 2013.
} 
Estou em processo de criação. Sinto poros abertos para o mundo. (Manuscrito da atriz Hylnara Anny. Água, Flores e Anjinhos, 2013).

Nessa memória afetiva, pessoal e universal que vem à tona no texto, para pôr em cena temas como a morte, violência e o estar no mundo, processamos impulsos e sensações que afetam, seja pela frieza ou distancia ou no grito-berro da denúncia daqueles fantasmas nossos [...] em uma busca por diálogos ou silêncios.

(Depoimento do ator Jota Júnior - baldio, 2017).

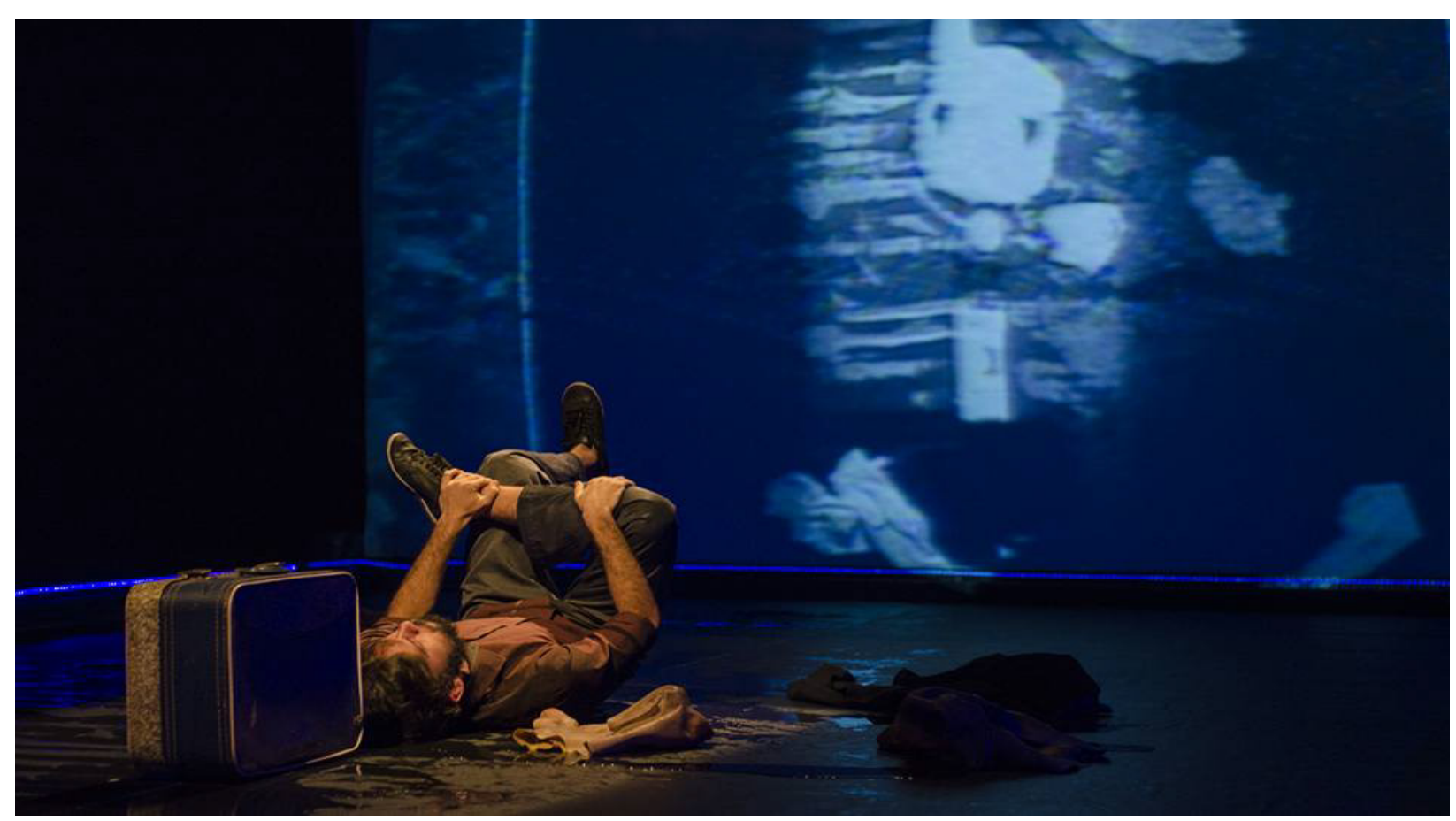

Cena com interface audiovisual em baldio; Ator: Eliel Carvalho. Foto: Arquivo do Grupo

\section{Da política da voz}

Como toda esta problemática implicada na movência permeia a poética das duas montagens aqui referenciadas? E, neste quadro, qual é a importância política da voz movente? Uma multiplicidade de referências interferiu no corpo da cena nestas montagens. Vale destacar que ambas operaram um cenário-instalação, lançando mão de recursos audiovisuais, o que intensificou o trabalho sonoro-vocal, assim como a relação entre palco e platéia, potencializando esse encontro sonoro. O certo é que nestas montagens a relação multireferencial entre voz e palavra se tornou decisiva, como podemos perceber, por exemplo, nos manuscritos das atrizes em Água, Flores e Anjinhos:

A voz que transpõe a palavra dita. A voz reatora de sensações, imagens, memórias, sabores, cheiros. [...] Experiências sensoriais. (Manuscrito da atriz Gabriela Araruna. Água, Flores e Anjinhos, 2013).

A voz escoa, ecoa, entoa, emociona, faz suar, passa pelo tronco da gente feito uma mistura poderosa de ácido e fogo e mexe fisicamente. (Manuscrito da atriz Raquel Capelo. Água, Flores e Anjinhos, 2013). 
Nesta montagem, de fato, intensificamos a performatividade dramatúrgica do texto de Denys, com seus coros, aliterações, jorros de palavras substantivas, entre outros, a fim de produzir uma dinâmica rítmica para deflagrar uma dinâmica sonora da voz. Com esta materialidade poética, Água, flores e anjinhos se configurou em uma cadência de ambiências sonoras que constituíram sua dramaturgia cênica.

Já baldio operou sua poética dramatúrgica por fragmentos, por cacos das histórias pessoais das atrizes e dos atores, transformadas pelo dramaturgista em materiais textuais. Estes foram sendo alinhavados por meio de aliterações, flashbacks, frases entrecortadas, a fim de operar uma espacialização sonora das palavras, uma espécie de musicalidade do texto. Aqui vale ressaltar a figura do cão, no som do uivo, que vai formatando o teor sensível da poética cênica de baldio. No programa desta montagem consta o seguinte:

\footnotetext{
Nos ressoa e inspira a imagem daquele cão do conto de Shaun Tan, que resiste, sentado em cima de uma TV, ao esquecimento da morte violenta de um outro cão. O cão uiva, uiva, uiva... a força da imagem é a força desse uivo, desse corpo, desse uivo, desse espaço, desse uivo, dessas palavras, desse uivo... Tudo isto reverbera na criação dos atores, em memórias que oscilam entre as palavras, entre os elementos da cena, as imagens, os mesmos atores, porque se sabem ficções, cenas, memórias de memórias... daqueles que não foram... onde chove... uivos ao longe... de um lugar baldio (Briones, in: Pavilhão da Magnólia, 2015).
}

Uma das histórias na montagem é, com efeito, a deste cão $\nabla$ e esta não é falada, mas, sim, projetada em palavras que devem ser lidas em um telão, de maneira silenciosa pelos espectadores. Silêncio que se instaura logo após uma cena violenta e extremamente ruidosa. Este silêncio, arriscamos aqui, além de operar um jogo intertextual com a linguagem literária, por via reversa, também o faz com a sonoridade, em um sentido mínimo. As palavras soam, poderíamos dizer, na memória do espectador. Algo similar ocorre com uma cena das atrizes, quando esta narra a separação dos seus pais, do ponto de vista da incompreensão de quando era criança, em um tom intimista, de baixo volume, em um microfone. Esta atriz comenta sobre esta cena:

[...] esse lugar do trauma que trazemos à cena é como se fosse uma voz embargada que não quer sair, e que o microfone insiste em ampliar, é por ora uma voz de denúncia, uma voz que precisa chegar a todos, é a voz cotidiana que por vezes aproxima o público de cenas que possivelmente esses espectadores já vivenciaram em algo semelhante. (Depoimento da atriz Silviane Lima, 2017)

Suas palavras eram ditas em um tom vocal de volume mínimo, em um texto que misturava a narração de cenas de um filme de um outro menino que estava atrás de sua mãe - um jogo intertextual com o filme Paris, Texas de Wim Wenders -, onde as palavras eram enunciadas e logo eram inundadas no silêncio, de um não querer falar.

O silêncio, exemplificado nestas duas cenas - a do conto projetado e a da menina que narra a separação - evidencia um sutil e incisivo vínculo com a memória, talvez como reminiscências baldias da cidade, sinal de uma difícil ferida social. Aqui se expõe o corpo-social da performance. É justamente este vínculo com a memória que ressoa nesse silêncio, mas não só nele, pois o mesmo vínculo ressoa no uivo do cão como no urro da vaca de Água, Flores e Anjinhos. 
A história exposta em Água, Flores e Anjinhos é justamente a de uma contundente ferida histórica de mortes e violências, reprocessadas vocalmente em cena com o texto de Denys. O Nordeste aqui apresentado dista de um folclorismo tradicional já que com ele se indaga a violência do cangaço, de filhos mortos, de mães desamparadas, de mulheres sós que cantam com suas vozes as suas dores. Trata-se de um Nordeste sombrio, cuja difícil esperança reside em sua força religiosa, que se expressa nos seus cantos esgarçados, nas suas vozes. Nesta montagem, foi constante o relato das atrizes, durante o processo de criação, de um vertiginoso mundo afetivo mobilizado pelas vozes acessadas. E essas vozes eram acessadas pelas marcas da história de um Nordeste vivido por elas e ao mesmo tempo uma outra voz, um outro Nordeste condensado, de uma ou outra maneira, neste texto de Denys, assim como, no manuscrito de uma das atrizes:

\section{Abrirei meus lábios \\ Em tristes assuntos, \\ Para sufragar \\ Aos fiéis defuntos \\ (Denys, 2005, p. 28).}

Repleta de sonhos e desejos deixa-me ser outras. Algumas vezes vívida, em outras, cheia de dor, e o grande jogo era como sentir [...]. Quando acesso as lembranças das mulheres fortes e frágeis e cheias de fé e chorosas... lembro da minha mãe. (Manuscrito da atriz Roberta Bernardo).

No que diz respeito a baldio, suas histórias pessoais configuram uma versão suburbana da cidade. Versão esta que destoa das versões mercadológicas com as quais as cidades - e Fortaleza segue este padrão, com slogans como "a cidade da luz", "a cidade do sol" - se ofertam turisticamente. Deste modo, se formata o status pretensamente democrático das urbes na atualidade, querendo borrar de sua superfície todo desacerto (Richard, 2001), todo efeito desviante que venha a evidenciar suas contradições socioculturais. Esta lógica impõe um "tempo liso e homogêneo" da história (Benjamin,1993), que sistematicamente borra outras temporalidades possíveis, como um tempo presente pleno e autossuficiente, que assume o passado somente na medida em que este pode reforçar sua normatividade social no presente. Já o "tempo-agora" - termo proposto por Benjamin (1993, p. 229) - abre o presente na sua multiplicidade, mas não em uma multiplicidade cultural sedutoramente televisiva, senão em uma multiplicidade carregada de ecos de vozes mudas.

É precisamente neste exato momento, nesse instante único da performance, como dito acima, que a voz poética, na sua movência, mostra sua face eminentemente crítica. Aqui se intensifica o teor sensório da voz, do urro, do uivo, que atravessam estas duas montagens, cada uma em suas diferenças poéticas. Esta sonoridade não é puramente sinal de uma fisicalidade da voz, ensimesmada em sua corporeidade, na força de uma presença plena, da força do abraço que envolve o espectador. $\mathrm{Na}$ realidade, 'presença' não é a melhor palavra, pois aqui não há plenitude e sim um saturamento de tensões, que apontam outras dobras no presente social a partir da cena. Inclusive Zumthor, que comenta em diversos momentos de seus textos da voz enquanto 'presença', aponta a mesma como uma instância precária. Ele $(2014$, p. 78) 
diz: "A percepção [a força do encontro] é profundamente presença [...] Mas nenhuma presença é plena, não há nunca coincidência entre ela e eu. Toda presença é precária, ameaçada".

Neste sentido, urro e uivo apontam, na realidade, para uma visceralidade política, cuja singularidade diz de um movimento diferencial com a memória no presente. Se a voz poética é a que possibilita, diz Zumthor (2001, p. 139), a coesão do grupo social, da comunidade, pelo seu vínculo com a memória, esta relação se dá de maneira paradoxal, pela sua carga de esquecimento. Isto porque no liame comunitário, produzido pela voz poética, o que se pode entender por comum talvez "seja menos o que temos em comum, nós, seus ouvintes, do que isto que nos é comum a todos e, do mesmo modo, impossível: para além de nossas fronteiras, o rosto daquilo que a nós, indivíduos, seria a morte" (Zumthor, 2001, p. 142). Quer dizer, esta noção do comum se dá nessa precariedade da 'presença', nos vestígios, nos murmúrios, nas vozes quebradas do nosso tempo. Trata-se de uma linguagem suficientemente quebrada, precária (Richard, 2001), de sintaxes livres na cena, não dominantes, que possam abrir no presente suas outras temporalidades, dar vazão aos ecos de vozes mudas. Como comentam os atores de baldio e de Água, flores e anjinhos:

[...] me chama a atenção a constante variação da agressão e da delicadeza naquelas falas que são praticamente cotidianas. (Depoimento da atriz Silviane Lima - baldio, 2017).

Fechei os olhos e fui. [...]. Percebia-me cheia de vida, de lembranças, marcas, cicatrizes, que eu nem sei se foram produzidas em mim ou se as roubei das mulheres que por mim passaram.

(Manuscrito da atriz Roberta Bernardo - Água, flores e anjinhos, 2013).

[...] aquela história, então, não é mais nossa, mas também é nossa, podem-se reavivar nelas memórias que são coletivas

(Depoimento do ator Nelson Albuquerque - baldio, 2017).

Emitir sons de forma diferente do habitual. Ouvir não somente com os ouvidos. Captar sons através dos olhos, da pele, das mãos, do abdômen. Acessei lugares até então inimagináveis. [....]. Foi como morrer. Foi como perder tudo e ganhar tudo com outro significado. Diferente eu.

(Manuscrito da Atriz Ângela Deyva. Água, flores e anjinhos, 2013).

[...] o que importa neste jogo da palavra e da memória é a equalização da voz no espaço, no corpo e no espaço, isso gera outras vozes.

(Depoimento da atriz Denise Costa - baldio, 2017).

A pensadora da crítica cultural Nelly Richard, que vai pensar esta liberdade da sintaxe na arte em tempos atuais, comenta da importância dessas "significações difusas de materiais demasiado imprecisos que resistem às generalizações [...e...] que recolhem o desafio de converter o desunificado, o inconexo e o vagabundo dos restos em uma poética da memória" (Richard, 2001, p. 79 [tradução nossa], [grifo, em itálico, dos autores] $)^{12}$. Isto vai tumultuar a estabilidade dos sentidos, ali onde o presente

\footnotetext{
12 "significaciones difusas de materiales demasiado imprecisos que se resisten a sus generalizaciones [...e...] que recogen el desafío de convertir lo desunificado, lo inconexo y lo vagabundo de los restos en una poética de la memoria". (Richard, 2001, p. 79). (Tradução nossa).
} 
midiático não só esvazia os sinais da violência de suas convulsões de sentido, mas rompe os liames entre política e sensibilidade (Richard, 2001, p. 43). A voz poética, na sua força de movência, vai justamente fazer esse liame, de uma política que atenda a uma sensibilidade precária do presente, abrindo-o, fendendo-o, explorando redes inusitadas do saber social. Expõe o teor conflitante e insubmisso da memória, que afeta o fluxo caótico das intervocalidades, possibilitando a movência, que se dá em impactos sensórios que burlam a normatividade de uma sintaxe demasiada obediente às categorias de sentido. A força sonora da voz, nestas montagens, é a força desse uivo, desse corpo, desse urro, dessas palavras em vocalidades poéticas.

\section{Referências}

BASÍLIO, Astier; MAGNÓLIA, Pavilhão da. baldio. Texto da montagem homônima, não publicada.

BENJAMIN, Walter. Obras escolhidas. Magia e técnica, arte e política: Ensaios sobre literatura e História da Cultura. São Paulo: Brasiliense, 1993.

CAVARERO, Adriana. Vozes Plurais: filosofia da expressão vocal. Belo Horizonte: Ed. UFMG, 2011.

DENYS, João. Flores D’América. Recife: UFPE, SESC Pernambuco, 2005.

FISCHER-LICHTE, Érika. Estética de lo Performativo. Madrid-España: Abada Editores S.L., 2011.

GRAU, Carlos Garatea. El problema del cambio linguístico en Ramón Menéndez-Pidal: el indivíduo, las tradiciones y la historia. Tübingen, Germany: Gunter Narr Verlag. 2005

LPCA - Laboratório de Poéticas Cênicas e Audiovisuais. Portfólio virtual disponível em https://lpca.46graus.com/. Acesso em: 14 dez 2017.

MUGUERCIA, Magaly. Decir la Performance. Revista CELCIT, n 35-36, Buenos Aires Argentina: CELCIT, 2009, p. 135-139

RICHARD, Nelly. Residuos y Metáforas: Ensayos de crítica cultural sobre el Chile de la Transición. Santiago-Chile, Ed. Cuarto Propio, 2001.

SHAUN, Tan. Contos de lugares distantes. São Paulo: Cosac Naif, 2012.

ZUMTHOR, Paul. A Letra e a Voz. São Paulo: Companhia das Letras, 2001. 
ZUMTHOR, P. Performance, recepção, leitura. Trad. Jerusa Pires Ferreira e Suely Fenerich. São Paulo: Cosac \& Näif, 2010.

Recebido em: 05/01/2018

Aprovado em: 12/01/2018 